Journal of Maternal and Child Health (2018), 3(1): 44-58

https://doi.org/10.26911/thejmch.2018.03.01.05

\title{
Psychosocial Factors Associated with Anxiety and Delivery Pain
}

\author{
Shofia Maharani Khoirun Nisa'), Supriyadi Hari Respati²), Bhisma Murti') \\ 1)Masters Program in Public Health, Universitas Sebelas Maret \\ 2)Department of Obstetrics and Gynecology, Dr. Moewardi Hospital, Surakarta
}

\begin{abstract}
Background: Anxiety and pain are physiologic symptoms experienced by mothers during birth delivery. However, if these symptoms are not well-managed they can cause low birth weight, prematurity, prolonged labor, and postpartum depression. This study aimed to analyze the psychosocial factors associated with anxiety and delivery pain.

Subjects and Method: This was an analytical observational study with cross sectional design. The study was conducted at Gajahan community health center, Surakarta Hospital, and Muhammadiyah Hospital, Delanggu, Central Java, from December 2017 to January 2018. A total sample of 166 delivery mothers were selected for this study by purposive sampling. The dependent variables were anxiety and delivery pain. The independent variables were parity, psychological stress, coping mechanism, family income, and family support. The data were collected by questionnaire. Anxiety was measured by modified Pregnancy Related Anxiety Questionaire (PRAQ_R). The data were analyzed by path analysis.

Results: Delivery pain increased with higher anxiety $(b=0.30, S E=0.02, p<0.001)$. Anxiety decreased with higher delivery pain $(\mathrm{b}=-1.19, \mathrm{SE}=0.02, \mathrm{p}<0.001)$ and increased with higher stress $(\mathrm{b}=0.92, \mathrm{SE}=0.09, \mathrm{p}<0.001)$. Anxiety decreased with coping mechanism $(\mathrm{b}=-0.31, \mathrm{SE}=0.08$, $\mathrm{p}<0.001)$ and parity $(\mathrm{b}=-0.86, \mathrm{SE}=0.37, \mathrm{p}<0.001)$. Stress decreased with better coping mechanism $(b=-0.48, \mathrm{SE}=0.08, \mathrm{p}<0.001)$, higher family income $(\mathrm{b}=-0.16, \mathrm{SE}=0.04, \mathrm{p}<0.001)$, parity $(b=-2.13, S E=0.36, p<0.001)$, and stronger family support $(b=-0.22, S E=0.06, p=0.007)$. Coping mechanism increased with parity $(\mathrm{b}=1.39, \mathrm{SE}=0.33, \mathrm{p}<0.001)$ and strong family support $(\mathrm{b}=0.46, \mathrm{SE}=0.06, \mathrm{p}<0.001)$.
\end{abstract}

Conclusion: Delivery pain increases with higher anxiety. Anxiety associated with delivery pain, stress, and coping mechanism.

Keywords: delivery pain, anxiety, psychosocial, family income, parity, coping mechanism, stress

\section{Correspondence:}

Shofia Maharani Khoirun Nisa. Masters Program in Public Health, Universitas Sebelas Maret, Jl. Ir. Sutami 36 A, Surakarta 57126, Central Java. Email: shofiamkn@gmail.com.

Mobile: +6285736382926

\section{BACKGROUND}

Giving birth is the physiological process that every woman experiences. However, the process is not always easy and comfortable. One of maternal discomforts is anxiety. Anxiety is a natural feeling characterized by feelings of deep and continuous fear or concern (Hawari, 2001). Anxiety is a physiological thing experienced by the mother before the birth delivery because in that process there is a series of physical and psychological changes that start from the uterine contractions, dilation of birth canal, and expenditure of baby and placenta. If maternal anxiety is not handled properly, it can lead to preterm labor and prolonged labor in the mother, whereas a prolonged delivery of the baby may result asphyxia. In addition, according to (Hurlock, 1997), anxiety and depression are two types of psychiatric disorders that are related. Mothers who experience anxiety during labor have a greater risk of developing postpartum depression. If this is not 
handled properly, it will increase maternal and infant morbidity and mortality.

Some studies mention that depression rates during the first trimester of pregnancy are similar to normal anxiety in general while depression levels during the second and third trimesters are almost two times of the first trimester. A survey conducted at Columbia in 650 low-risk pregnant women with 35-39 week gestational age (25\%) experienced high levels of fear for childbirth and this correlated positively with anxiety (Misri \& Kendrick, 2007). Research in Hong Kong in first, second and second trimester women (54\%) shows that they experienced anxiety, 37\% of them experienced depressive symptoms (Madhavanprabhkaran, et al., 2015). A study about anxiety was also conducted in Pakistan, 165 pregnant women (70\%) experienced anxiety and depression (Chan et al., 2013).

Fear, anxiety, stress and excessive anger during pregnancy can result in a possible risk of a low birthweight child, small head size, unbalanced neurological development, premature birth, weakened immune system and emotional disturbance after birth become higher than mothers who undergo pregnancy with heart and feelings of happiness (Karmaliani et al., 2009).

Terry et al. (2007) states that anxiety has a great effect on both the quality and on the intensity of the pain experience. Restless patients are more sensitive to pain and from what is described, neurotic patients (who usually have high levels of anxiety) complain about pain more often than other patients. The pain threshold is reduced due to an increase in anxiety and leads to resentment of perceived pain. Fear of pain or anticipation of a high level of pain will increase anxiety, which in turn will cause a circle that continues to spin, as the anxiety increase will lead to the increase of pain sensitivity.

Pain is a body defense mechanism that arises when there is a damaged tissue by moving the pain stimulus (Sudarti \& Judha 2012). Birth pain is a physiological thing experienced by mothers, but most women consider that pain during labor is the greatest pain every woman feels (CostaMartins et al., 2014). Although not through a pathological process, normal labor is still considered a very painful process.

A study conducted by (Geisser et al., 2003) revealed that $90 \%$ of women experience pain labor with $37 \%$ of moderate pain. The pain experienced by maternal women has many factors including family support, age, parity and perception of pain having a significant effect on perceived pain.

Based on a study conducted by (Oh et al., 2015), anxiety and pain have a reciprocal relationship. Anxiety is a common condition that accompanies severe pain. The function of pain is as a danger signal when there is something wrong from the body that needs attention. In labor pain, this will cause the patient to focus on the pain and cause anxiety. This causes the patient anxiety and chronic muscle tension and add to the pain. According to the study of (Means-Christensen et al., 2008), it is stated that patients with muscle pain, headaches or abdominal pain about 2.5 to 10 times are at risk of panic attacks, anxiety disorders and major depression.

During the birth delivery, the mother experiences environmental and psychological changes. Therefore, it is necessary to adjust to these changes so that they will not cause problems during labor.

Coping mechanisms during birth delivery can reduce tension and pain. This is supported by a study conducted by (Geisser et al., 2003) which states that 
Journal of Maternal and Child Health (2018), 3(1): 44-58

https://doi.org/10.26911/thejmch.2018.03.01.05

mothers experience anxiety during labor. Coping mechanisms are influenced by different aspects, such as family income, age, optimism parity, linkage between stressors and family support (Akiki et al., 2016).

Family support, age, parity, stress, low economic status, birth history, history of violence are frequently reported predictors (Waqas et al., 2015; Meulen, 2016). Prenatal depression, poor pregnancy history, poor family relationships, low socioeconomic status, low education level, unwanted pregnancies, complications during pregnancy are the determinants of anxiety and labor pain (Meulen, 2016). A high level of anxiety can improve labor pain, and vice versa (de Heer et al., 2014).

Anxiety and labor pain have a direct impact on the mother and long-term risks to maternal and infant health. In addition to causing LBW, preterm delivery and prolonged labor of anxiety in labor may increase the risk of postpartum depression (Terry et al, 2007).

Based on the description above, the researchers are interested in conducting research on psychosocial factors related to anxiety and labor pain. Psychosocial factors associated with anxiety and labor pain are family income, family support, age, parity, coping mechanisms, psychological stress. Considering the birth delivery rate in Surakarta which increased, then this study was conducted in several maternity hospitals and public health centers in the Surakarta and surrounding areas.

\footnotetext{
SUBJECTS AND METHOD

1. Study Design

This was an analytic observational study with a cross sectional design. The study was conducted in Klaten district, Central Java, from December to January 2018.
}

\section{Population and Sample}

The target population in this study were all primigravida and multigravida pregnant women in Surakarta and its surroundings, while the source population was in giving birth mothers research at Gajahan Health Center, Surakarta Hospital and PKU Muhammadiyah Delanggu Hospital and the samples in this study were 166 subjects selected using purposive sampling. The inclusion criteria in this study were primigravida and multi gravida pregnant women with 37-41 weeks of pregnancy with live single fetus, head presentation, vaginal delivery plan, in active stage I (active phase $4 \mathrm{~cm}-\leq 6 \mathrm{~cm}), \mathrm{TFU}<40 \mathrm{~cm}$. The exclusion criteria of this study were pregnant women who refused to be the subject of this study, there were maternal diseases, and there was intervention in labor (such as induction and / or stimulation).

\section{Operational definition of variables}

Anxiety in labor was defined as an unpleasant anxiety experienced by a mother that can cause anxiety due to a labor that will take place. The data were collected by Pregnancy Related Anxiety Questionaire (PRAQR).

Pain was defined as a pain that is felt by the mother as a result of the labor process causing a pain response. The data were collected by Visual Analog Scale observation sheet (VAS).

Family support was defined as support from parents / relatives / people /their closest ones in the form of helping or paying attention to the subjects who experience anxiety and labor pain. The data were collected by questionnaire that refers to Friedman's theory.

The coping mechanism was defined as a way for individuals to solve a problem and to adjust to the change in response to a situation in the face of labor pain. The data were collected by questionnaire which 
refers to the standard questionnaire of Brief Cope.

Psychological stress was defined as a feeling of mental or emotional disturbance or disturbance experienced by a laboring mother who experiences anxiety and labor pain and raises a person's psychological / psychiatric problems (tension and anxiety). The data were collected by questionnaire that refers to the standard questionnaire ISMA (International Stress Management Association).

Family income was defined as money received by mothers and families every month to meet daily needs calculated using an average of 6 months before the data collection. The data were collected by questionnaire.

Parity was defined as the number of fetus with body weight $\geq 2,500$ gram ever born by the subjects either life or death. The data were collected by questionnaire.

\section{Data Analysis}

The data analysis used path analysis with SPSS AMOS 22 program to know the effect

\section{Table 1. Sample Characteristics}

\begin{tabular}{lcc}
\hline Characteristics & n & \% \\
\hline Age & 11 & 6.6 \\
<20 years old & 151 & 91 \\
20 - 35 years old & 4 & 2.4 \\
Paryears old & 69 & 41.6 \\
Primi gravida & 97 & 58.4 \\
Multi gravida & & \\
Family Income & 24 & 14.5 \\
<Rp 1,668,700 & 142 & 85.5 \\
ZRp 1,668,700 & & \\
Educational Background & 2 & 1.2 \\
PS & 34 & 66.5 \\
JHS & 111 & 4.2 \\
SHS & 7 & 7.2 \\
DIII & 12 & 6 \\
S1 Birth Delivery Place & & 42.2 \\
Gajahan PHC & 10 & 51.8 \\
Surakarta Hospital & 70 & \\
Muhammadiyah Delanggu hospital & 86 & \\
\hline
\end{tabular}

of variable, either direct and indirect influence. The steps of path analysis in this study were model specification, model identification, model equilibrium, parameter estimation and model respesification.

\section{Research Ethis}

This study included the approval of the study (informed consent) by the subject of research, anonymousity, confidentiality, and ethical clearance of research committee from Moewardi hospital, Surakarta.

\begin{tabular}{l}
\hline RESULTS \\
\hline 1. Sample Characteristics \\
The characteristics of the study subjects \\
shown in Table 1 explain that of the 166 \\
study subjects, the majority of study \\
subjects were 20-35 years old (91\%) and a \\
small fraction is over 35 years (2.4\%). Most \\
of the study subjects were multigravida \\
(58.4\%) and a minority of them was \\
primigravida $(41.6 \%)$.
\end{tabular}


Journal of Maternal and Child Health (2018), 3(1): 44-58

https://doi.org/10.26911/thejmch.2018.03.01.05

Most of the study subjects had a family income of more than Rp 1,668,700 (85.5\%) and a small portion had income less than Rp 1,688,700 (14.5\%). Most of the subjects were senior high school graduates $(66.9 \%)$ and a small proportion was elementary school graduates (1.2\%). Most of the subjects gave birth at PKU Muhammadiyah Delanggu hospital (51.8\%).

\section{Univariate Analysis}

Description of research variables univariate explain about the general description of the data of each variable with continuous data including family income, parity, coping mechanism, psychic stress, anxiety and labor pain. Univariate analysis results can be seen in Table 2.

\section{Bivariate Analysis}

Bivariate analysis describes the influence of one independent variable to one dependent variable. The result of bivariate analysis shows that all independent variables significantly influence the occurrence of anxiety and labor pain. The result of bivariate analysis is shown in Table 3 .

Table 2. The Result of Univariate Analysis

\begin{tabular}{lccccc}
\hline \multicolumn{1}{c}{ Variable } & N & Mean & DS & Min. & Max. \\
\hline Family Income & 166 & 19.65 & 6.93 & 3 & 5 \\
Family Support & 166 & 15.9 & 4.52 & 1 & 20 \\
Parity & 166 & 1.95 & 0.91 & 1 & 5 \\
Coping Mechanism & 166 & 14.28 & 4.64 & 1 & 20 \\
Psychic Stress & 166 & 8.86 & 5.9 & 0 & 20 \\
Birth Delivery Anxiety & 166 & 7.61 & 5.86 & 0 & 20 \\
Birth Delivery Pain & 166 & 4.82 & 1.98 & 0 & 9 \\
\hline
\end{tabular}

Table 3. Pearson product moment bivariate correlation

\begin{tabular}{lcc}
\hline Independent Variable & $\mathbf{r}$ & $\mathbf{p}$ \\
\hline Family Income & -0.251 & 0.001 \\
Family Support & -0.483 & $<0.001$ \\
Parity & -0.595 & $<0.001$ \\
Coping Mechanism & -0.639 & $<0.001$ \\
Psychic Stress & 0.85 & $<0.001$ \\
\hline
\end{tabular}

Table 2 shows that each variable has a small standard deviation. The mean describes the mean value, while the standard deviation (SD) describes how varied the data variations are. If the $\mathrm{SD}$ value is much larger than the mean, then the mean value is a poor representation of the overall data, whereas if the SD value is very small compared to the mean value, then the mean value can be used as a representation of the whole data. Data Table 2 shows the SD values corresponding to the mean so that the mean can be used as a representation of the overall data.
Table 3 shows that the results of the Pearson product moment correlation test of family income, family support, parity, coping mechanism, psychological stress with anxiety in labor, result $r=-0.25$ with $\mathrm{p}=0.001$. This suggests that there is a significant relationship between family income and anxiety about labor. Family income can affect anxiety in the facing the birth delivery. The higher the family income, the less anxiety a person is.

The result of Pearson product moment correlation test about relation of family support with anxiety faced during 
labor, shows that the value $\mathrm{r}=-0.48$; $\mathrm{p}$ $<0.001$. This suggests that there is a significant relationship between family support and anxiety about labor. A person's family support can affect anxiety about labor. Family support given to mothers can help to reduce the anxiety of childbirth.

The result of Pearson product moment correlation test about parity relation with anxiety faced during labor, shows that the value $r=-0.59$ with value $p$ $<0.001$. This suggests that there is a significant relationship between parity and the anxiety of labor. The higher the parity of the study subjects may affect the anxiety of labor. High parity can decrease anxiety in facing the delivery of research subjects.

\section{Multivariate Analysis}

Path analysis was used to determine the influence of a variable other both the direct and indirect influences. The magnitude of the influence of independent variables on the bound is called path coefficient.

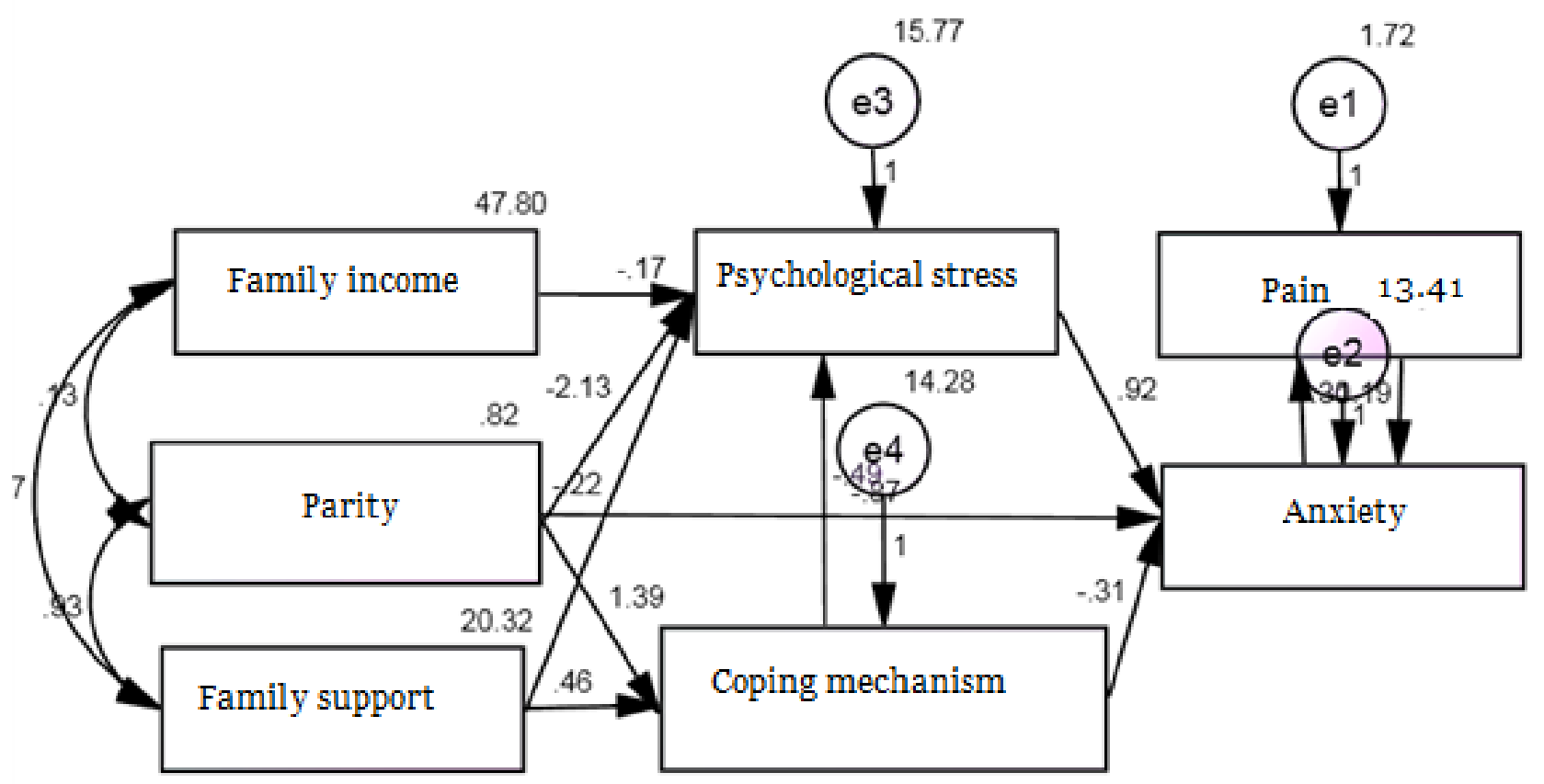

Figure 1. Structural Model of Path Analysis

Figure 1 shows the structural model after the estimation using IBM SPSS AMOS 22, so that the scores are obtained which be can be seen in the picture. Indicators which indicate the suitability of the path analysis model as shown in Table 4 also indicates the goodness of fit measure, that the result of fit index (CMIN index) of 8.20 with $p$ score $=0.315>0.05 ;$ GFI (Goodness of Fit Index) $=0.98 \geq 0.90$ NFI (Normed Fit Index) $=0.98 \geq 0.90 ;$ CFI (Comparative Fit Index) $=0.99 \geq 0.90$; RMSEA (Root
Mean Square Error of Approximation) = $0.32 \geq 0.08$ which mean that the empirical model met the criteria specified and expressed in accordance with the empirical data.

Table 4 shows the result analysis of the path relationship between family income, parity, family support, coping mechanisms and psychological stress on anxiety and delivery pain using the IBM SPSS AMOS 22 computer program. In every enhancement of one anxiety unit, it 
will increase the pain by 0.3 unit $(b=0.3$, $\mathrm{SE}=0.02, \mathrm{p}<0.001)$. In every enhancement of one pain unit, it will increase the anxiety unit by $0.3(b=1.19, \mathrm{SE}=0.02, \mathrm{p}<0.001)$.

In every enhancement of one psychological stress unit, it will increase the anxiety by 1 unit $(b=0.92, S E=0.09$, $\mathrm{p}<0.001)$. In every enhancement of one coping mechanism unit, it will decrease the anxiety by 0.21 unit $(b=0.31, \mathrm{SE}=0.08$, $\mathrm{p}<0.001)$. In every enhancement of one

Table 4. Results Analysis of the Study Variable Path

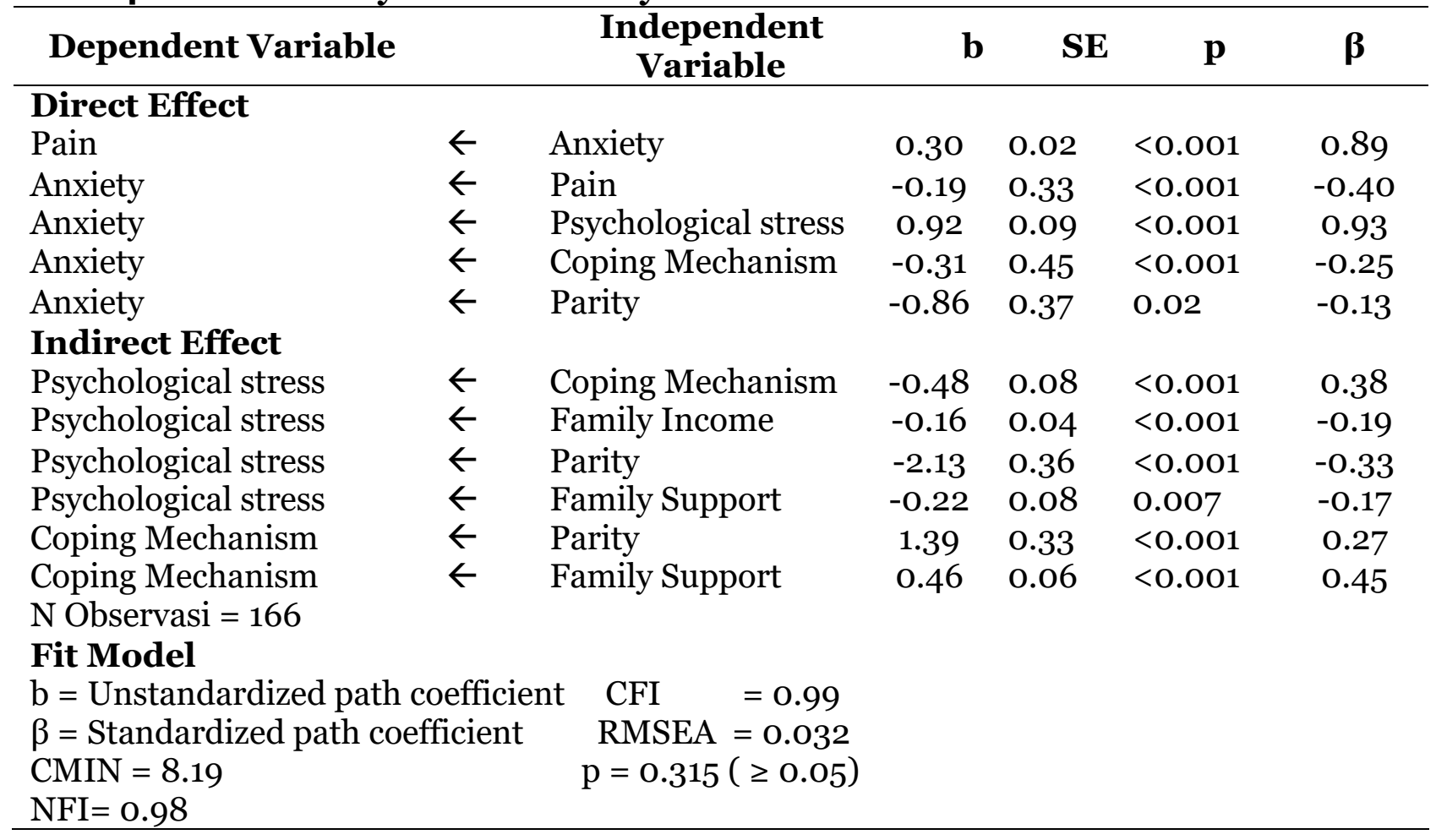

In every enhancement of one parity unit, it will decrease the psychological stress by 2.13 units $(b=2.13, \mathrm{SE}=0.36$, $\mathrm{p}<0.001)$. In every enhancement of one family support unit, it will decrease the psychological stress by 0.22 unit $(b=0.22$, $\mathrm{SE}=0.06, \mathrm{p}=0.007)$. In every enhancement of one parity unit, it will increase the coping mechanism by 1 unit $(b=1.39, \mathrm{SE}=0.33$, $\mathrm{p}<0.001)$. In every enhancement of one family support unit, it will increase the coping mechanism by 0.46 unit $(b=0.46$, $\mathrm{SE}=0.06, \mathrm{p}<0.001)$. parity unit, it will decrease the anxiety by 0.86 unit $(b=0.86, S E=0.37, p<0.001)$. In every enhancement of one coping mechanism unit, it will decrease the psychological stress by 0.48 unit $(b=0.48, \mathrm{SE}=0.08$, $\mathrm{p}<0.001$ ). In every enhancement of family income by $\mathrm{Rp}$. 100,000, it will decrease coping mechanism unit, it will decrease the psychological stress by 0.16 unit $(b=0.16$, $\mathrm{SE}=0.04, \mathrm{p}<0.001)$.

The model in this study is already in accordance with the sample data as shown by path coefficient which is more than zero, and it is statistically significant. Therefore, the respecification model is not needed.

\section{DISCUSSIONS \\ 1. The relationship between family income and the anxiety in delivery process}

The path analysis result in this study showed that there was a negative indirect relationship between family income and the anxiety which was statistically significant. 
This was in line with a study done by Melchoir et al, (2010) which stated that there was a significant relationship between family income and the anxiety in facing the delivery/labor.

Family income is the income earned by family members which are used to fulfill the needs of daily life. The income can be either money or goods paid by the company, office, or employer (BPS, 2013). The level of income can affect a person's perspective in making decisions, including the decision to choose a health facility to be used for delivery. A person who had some fixed income tend to want to delivery in a good health facility (Meulen, 2016). The cost of delivery/labor was one of the burdens that cause stress in pregnant women. High family income decreased the stress in pregnant women during the delivery so that it decreased the level of anxiety in delivery process. In addition, the relationship between family income and anxiety can also be caused by coping mechanism factor. High family income can increase the coping mechanism that can decrease the psychological stress and the maternal anxiety in delivery (Rini, 2016). However, the results of path analysis in this study did not show that there was a positive direct relationship between family income and coping mechanism.

The economic level of a family has a strong relationship with the preparation in delivery. With high family income, the maternal mothers can received a complete ANC check up, therefore, the knowledge and preparation of delivery were better than mothers with low family income (Din et al., 2016).

\section{The relationship between family support and the anxiety in delivery process}

The path analysis result in this study showed that family support has a negative indirect relationship with the anxiety through coping mechanism and psychological stress which was statistically significant. The result of this study was in line with a study done by Madhavanprabhakaran et al, (2015).

Family support is a beneficial situation for individuals which is acquired from family members so that someone will know the feelings of getting attention, being appreciated, and loved (Chan et al., 2013). Labor or birth delivery is normal for every woman. However, most women considered delivery as the most frightening thing in their life. It was because during the delivery process, mothers were faced with conditions that can threaten their life and the babies. With family support, a maternal mother can share her complaints and get attention, therefore, she felt calm and comfortable in dealing with the delivery process.

In addition, with the support of maternal family, it was possible to obtain information about the delivery process and the way to minimize anxiety and delivery pain. Strong family support also allowed the maternity mothers to have better delivery preparation to improve the coping mechanism and reduce the psychological stress experienced by maternal mothers (Veringa et al., 2016).

\section{The relationship between parity and the anxiety in delivery process}

The path analysis result in this study showed that there was a negative direct and indirect relationship between parity and the anxiety which was statistically significant. In addition, parity showed a direct and indirect relationship with psychological stress, therefore, parity can lead to anxiety through coping mechanism and psychological stress. The result of this study was in line with a study by Waqas et al., (2015). Parity is the condition of women related to 
the birth of a living child (Dorland, 2002). In this case, women who have never experienced delivery are called pirimipara and women who have given birth before are called multiparas. The number of children born strongly affected the maternal health. At the first birth, there was a higher danger of complications compared to second or third births. The second or third birth was commonly safer, but at the fourth and subsequent births, the risk of infant and maternal mortality was higher (Apriliana, Maftuchah and Nurhudhariiani, 2014).

Primipara women did not have experience of giving birth, causing fear and anxiety of the delivery. Inexperienced mothers would have an impact on poor coping mechanisms and increased psychological stress, therefore, it affected the way to overcome the anxiety (Aziato et al., 2017).

\section{The relationship between coping mechanism and the anixiety in delivery process}

The path analysis result in this study showed that coping mechanism has a negative direct and indirect relationship with the anxiety which was statistically significant. The result of this study was in line with a study by Guardino, 2015; George et al., (2013).

The transition to becoming a mother lead to changes in some things including changes in family dynamics, finances and work life that adjust to the physical and psychological. In addition, at the time of delivery, there was a physiological process that can cause the mother to experience anxiety and pain. However, some women cannot overcome some of these changes due to poor coping mechanisms. This lead to the enhancement of psychological stress experienced by mother. Maternal mothers who experience psychological stress were through complex cognitive, behavioral, emotional and biological processes. The process of selecting a strategy was an evaluation of the personal competence of dealing with the problem. The ability to choose the right coping strategy would determine the mother and fetus to avoid the negative effects of psychological stress. For example, a mother who chose a coping strategy which was seeking emotional support, would get less negative impact of stress compared to mothers who chose a coping strategy which was smoking or drinking alcoholic beverages (Guardino, 2015).

\section{The relationship between psycho- logical stress and the anxiety in delivery process}

The path analysis result in this study showed that there was a relationship between psychological stress and anxiety which was statistically significant. The result of this study was in line with a study by George et al., (2013); Meulen, (2016); Klabbers et al., (2014). Psychological stress is a condition or state of the body that disturbed by psychological pressure. Psychological stress caused by maladaptive individuals in the form of coping that was destructive. The adjustment or normalizetion of a failed stressor lead to the tension and increased the concentration on a problem that was considered important. Excessive focus without control would override the constructive coping so that individuals would experience selective attention that was relatively misleading (Hidayat et al., 2015). Usually, psychological stress was not related to physical illness, but rather to psychological problems. Psychological stress can affect the physical function of the body including increased secretion of the cortisol hormone. The incident of psychological stress can also affect the endocrine function that can permanently change the hypothalamus pituitary gonad (HPG) 
regulation of a person's reaction. This activity lead to a problem in the secretion of the oxytocin hormone that served to stimulate uterine contractions (Benfield et al., 2014)

Psychological stress can interfere the work of the endocrine system. The endocrine system was disrupted when the myometrium in the secretory phase produced F2 prostaglandin which lead to the contraction of the smooth muscles so that it can caused pain during the delivery process. Someone who was emotionally unstable, especially if they did not get a good explanation about the delivery process can lead to anxiety in the delivery process. In addition, emotional stress and psychological-related tension before delivery clarified the severity of pain (Pettersson et al., 2016)

\section{The relationship between anxiety and delivery pain}

The path analysis result in this study showed that there was a positive direct relationship between anxiety and delivery pain. The enhancement of anxiety also increased the pain felt by the mothers and it was statistically significant. The result of this study was in line with a study by Means-Christensen et al., (2008).

Anxiety is a fear or worry in certain situations that are very threatening and can cause anxiety due to a threatening situation that leads to loss of confidence to face something. Anxiety is a natural thing, but if it has caused disruption, it would inhibit the role of someone in his/her life. Feeling tense during labor caused the muscles of the uterus to wrinkle, while the mothers hold their breath. This would inhibit the delivery process as a result of stress, both in mothers and fetuses. It also inhibited the oxygen needed by mothers and their fetuses. Tension would also make the delivery process to be more painful, and it required anesthesia to reduce the pain (Rose, 2012).

Anxiety has a great effect on both the quality and the intensity of the pain. Restless patients were more sensitive to pain, and from the description, neurotic patients (who usually have high levels of anxiety) complained of pain more often than other patients. The pain threshold was reduced due to the enhancement in anxiety and lead to the resentment of perceived pain. Fear of pain or anticipation of a high level of pain would increase the anxiety, which in turn lead to a continuous circle, because the enhancement of anxiety lead to an increase in pain sensitivity.

\section{The relationship between pain and the anxiety in delivery process}

The path analysis result in this study showed that there was a positive direct relationship between pain and the anxiety in delivery process which was statistically significant. The enhancement of pain score also increased the anxiety that was felt by the mothers. The result of this study was in line with a study by Whitburn et al., (2017)

Pain is a body defense mechanism that arises when there is a damaged tissue by moving the pain stimulus (Judha, 2012). Pain during the delivery is normal, because pain is a danger signal from damaged tissue by the labor opening. The function of pain is as a danger signal on the body that needs attention (McAllister, 2015). Severe pain can cause a medical problem that lead to the resistance in conventional medical treatment. Pain is a body defense mechanism that arises when there is a damaged tissue by moving the pain stimulus (Sudarti \& Judha 2012). Delivery pain is a physiological thing experienced by mothers, however, most women consider delivery pain as the greatest pain felt by every woman (Costa-Martins et al., 2014). Although it did not through a pathological 
process, normal delivery was still considered as a very painful process. The intensity of delivery pain can be classified as mild and severe as the intensity of contraction increased (Baker et al., 2001). At the beginning of delivery, pain occured due to the manifestation of abdominal pain, pelvic pain, and pain in the spine. The higher the number of delivery, the more severe the pain become (Aziato, Acheampong and Umoar, 2017).

Anterior Cingulate Cortex (ACC) is known to have a role in providing emotional connection and experience. In addition, ACC is thought to have an important role in severe pain. A study by Zhuo (2016) suggested that ACC might be the center of anxiety. In mothers with severe pain, the anxiety scores may be increased due to pain, and visual representation found that mothers who experienced anxiety also experienced an enhancement in ACC.

Anxiety and pain interact in different ways. Severe and prolonged pain may caused anxiety, while high anxiety scores increased the pain. High anxiety and severe pain may be a causal cycle that has a positive relationship with each other. It was difficult to determine which came first between anxiety and pain.

\section{REFERENCES}

Abdullah T, Leeden AC (1986). Durkheim dan Pengantar Sosiologi Moralitas. Jakarta: Yayasan Obor Indonesia.

Afroh F, Judha, Sudarti M (2012). Teori Pengukuran Nyeri \& Nyeri Persalinan. Yogyakarta: Nuha Medika.

Alehagen S, Wijima B, Lundber U, Wijma K (2004). Fear. Pain and Stress Hormones during Childbirth, Journal of Psychosomatic Obstetriics \& Gynecology. 26(3): 153-165.

Aziato L, Acheampong AK, Umoar KL (2017). Labour Pain Experiences and
Perceptions: a Qualitative Study among Post-partum Women in Ghana, BMC Pregnancy and Childbirth. BMC Pregnancy and Childbirth, 17(1): 73. doi: 10.1186/s12884-0171248-1.

Badan Pusat Statistik (2014). Anggaran Pendapatan Negara. Diakses dari www.bps.go.iddiakses pada tanggal 7 Agustus 2017.

Baker A, Ferguson S, Roach G, Dawson D. (2001) Perceptions of Labour Pain by Mothers and Their Attending Midwives. Journal of Advanced Nursing. Blackwell Science Ltd, 35(2), p : 171179. doi: 10.1046/J.1365-2648.2001.01834.X.

Barrett SJ, Stark MA (2010). Factors associated with labor support behaviors of nurses. The Journal of perinatal education. Lamaze International, 19(1): 12-8. doi: 10.1624/105812410X481528.

Beigi NMA (2010). Women's experience of pain during childbirth. Iranian journal of nursing and midwifery research. Wolters Kluwer. Medknow Publications 15(2): 77-82. Available at: http://www.ncbi.nlm.nih.gov/pubmed/21589784 (Accessed 8 November 2017).

Benfield RD, Newton ER, Tanner JC, Heitkemper MM (2014). Cortisol as a Biomarker of Stress in Term Human Labor: Physiological and Methodological Issues.Biological Research for Nursing. NIH Public Access, 16(1): 64-71. doi: 10.1177/1099800412471580.

Buff C (2016). Specifically Altered Brain Responses to Threat in Generalized Anxiety Disorder Relative to Social Anxiety Disorder and Panic Disorder, NeuroImage. Clinical. Elsevier, 12: 698-706. doi: 10.1016/j.nicl.2016.- 
09.023 .

Chan CY, Lee MA, Lam KS, Lee CP, Leung YK, Koh WY, Tang KSC (2013). Antenatal Anxiety in the First Trimester: Risk factors and Effects on Anxiety and Depression in the Third Trimester and 6-Week Postpartum, Open Journal of Psychiatry. Scientific Research Publishing, 3(3): 301-310. doi: 10.4236/ojpsych.2013.33030.

Chaplin JP (2011). Kamus Lengkap Psikologi. Jakarta; Raja Grafindo Persada: 45-47.

Chris WRN, David N, Judith A, Maloni JRK (2008). Pain Measurement During Labor: Comparing the Visual Analog Scale With Dermatome Assessment', Applied Nursing Research. W.B. Saunders, 21(2), pp. 104-109. doi: 10.1016/J.APNR.2006.05.002.

Costa-Martins JM, Pereira, M, MartinsH, Marian. 2014. The Role of Maternal Attachment in the Experience of Labor Pain, Psychosomatic Medicine, 76(3): 221-228. doi: 10.1097/PSY.o000000000000040.

Cunningham FG. 2014. Obstetri Williams. Jakarta ;EGC p : 98-105

Curzik D, Jokic BN (2011). Anxiety sensitivity and anxiety as correlates of expected, experienced and recalled labor pain, Journal of Psychosomatic Obstetrics \& Gynecology, 32(4): 198203. doi: 10.3109/0167482X.2011.626093.

Danuatmaja B. 2008. Persalinan Normal Tanpa Rasa Sakit. Jakarta: Puspa Swara pp. 14-23

De Heer EW (2014). The Association of Depression and Anxiety with Pain: A Study from NESDA, PLoS ONE. Edited by H. S. Sun, 9(10): e106907. doi: 10.1371/journal.pone.0106907.

Dimatteo MR (2004). Social Support and Patient Adherence to Medical Treat- ment: Meta Analysis. Health Psychology Journal. 23(2): 207-218.

Din Z, Ambreen U, Iqbal S, Iqbal M, Ahmad $S$ (2016). Determinants of Antenatal Psychological Distress in Pakistani Women, Noropsikiyatri Arsivi, 53(2): 152-157. doi: 10.5152/npa.2015.10235 .

Elizabeth BH (1997). Psikologi Perkembangan. Available at: http://www.entailed.web.id/2014/o6/kk.html

(Accessed: 8 November 2017).

Geisser ME, Robinson ME, Miller QL (2003). Psychosocial Factors and Functional Capacity Evaluation Among Persons With Chronic Pain, 13(4): 259-276.

Guardino CMSC (2015). Coping during pregnancy: a systematic review and recommendations, Health Psychol., 8(1): 70-94. doi: 10.1080/17437199.2012.752659.Coping.

Handayani (2014). Pengaruh terapi Murotal Al-Quran untuk penurunan nyeri persalinan dan kecemasan pad ibu bersalin kala I fase aktif. Jurnal ilmiah Kebidanan, 5(2): 1-15.

Hawari D (2001). Manajemen stress, cemas dan depresi. Health and Medicine Journal. Fakultas Kedokteran Universitas Indonesia. 4-7

Huizink AC, Defolterie MJ, Scheinin NM, Tolvanen M, Karlsson L, Karlsson H (2016). Adaption of Pregnancy Anxiety Questionnaire-revised for all Pregnant Women Regardless of Parity: PRAQ-R2, Archives of Women's Mental Health, 19(1): 125-132. doi: 10.1007/s00737-015-0531-2.

Heffner, Elkin E, Fretts RC (2003). Impact of labor induction, gestational age, and maternal age on cesarean delivery rates. Obstetrics and gynecology, 102(2): 287-93. Available at: http://www.ncbi.nlm.nih.gov/pubmed/1290 
Journal of Maternal and Child Health (2018), 3(1): 44-58

https://doi.org/10.26911/thejmch.2018.03.01.05

7101 (Accessed: 9 November 2017).

Jeffrey S, Nevid (2009). Psikologi Abnormal. Jakarta: Erlangga.

Kaakinen JK, Gedally-Duff VM Coehlo DP, Hanson SMH (2010). Family Health Care Nursing. 3rd edn. Jakarta. EGC.

Kail RV, Cavanaugh JC (2000). Human Development: A Life Span View 2th ed. United States: Wadsworth Thomson Learning.

Kaplan, Sadock (1997). Sinopsis Psikiatri: Ilmu Pengetahuan Psikiatri Klinis Jilid 2. Jakarta; Binnarupa Aksara: 67-70.

Kitab Undang-undang Perdata. Pasal 77 , Pasal 1393; 2 KUHPerdata.

Karmaliani R, Asad N, Bann C M, Moss N, McClure EM, Pasha O, Wright LL, Goldenberg RL (2009). Prevalence of Anxiety, Depression and Associated Factors Among Pregnant Women of Hyderabad, Pakistan, The International journal of social psychiatry. NIH Public Access, 55(5): 414-24. doi: 10.1177/0020764008094645.

Lang AJ (2006). Anxiety sensitivity as a predictor of labor pain', European Journal of Pain. No longer published by Elsevier, 10(3): 263-270. doi: 10.1016/J.EJPAIN.2005.05.001.

Manuaba IBG (2010). Ilmu Kebidanan, Penyakit Kandungan dan KB. Jakarta: EGC.

Madhavanprabhakaran GK, D’Souza MS, Nairy KS (2015). Prevalence of Pregnancy Anxiety and Associated Factors, International Journal of Africa Nursing Sciences. Elsevier Ltd, 3, pp. 1-7. doi: 10.1016/j.ijans.2015.06.002.

Maghfuroh A (2012). Faktor-faktor yang Berhubungan dengan Nyeri Persalinan Kala I fase Aktif di Ruang Bersalin Rumah Sakit Umum Kabupaten Tanggerang, Maternity Nursing, Syarif Hidayatullah Islamic University.
Malahayati I (2015). Pengaruh Dukungan Psikososial selama Persalinan terhadap Lama Persalinan dan Angka Kelahiran Sesar, Maternal and Childbirth.

Marlyn M, Friedman (1998). Keperawatan Keluarga: Teori dan Praktik (Edisi 3). Jakarta. EGC.

McAllister JM (2015) Anxiety and Pain, Institute for Chronic Pain. Available at://www.icp.com/relation of anxiety and pain.htm (Accessed: 1 February 2018).

Means-Christensen AJ (2008). Relationships among pain, anxiety, and depression in primary care, Depression and Anxiety. Wiley Subscription Services, Inc., A Wiley Company, 25(7): 593-600. doi: 10.1002/da.20342.

Medya R, Kristiaji WC, Jeffrey S (2010). Psikologi Abnormal= Abnormal psychology/ Jeffrey S . Nevid, Spencer A . Rathus, Beverly Greene.

Molton IR (2009). Psychosocial factors and adjustment to chronic pain in spinal cord injury: replication and crossvalidation. Journal of rehabilitation research and development, 31-42. doi: 10.1682/JRRD.2008.03.0044.

Murti B (2013). Desain dan Ukuran Sampel untuk Penelitian Kuantitatif dan Kualitatif. Yogyakarta: UGM press.

Peraturan Presiden RI Nomor 72 tahun 2012 tentang Sistem Kesehatan Nasional. http://binfar.kemkes.go.id/?wpdmact $=$ process\&did=MTEoL mhvdGxpbms $=$ diakses 1 Oktober 2017.

Pettersson FD, Hellgreen C, Nyberg, Fred, Akerud H, Sundstrom-Poromaa I (2016). Depressed mood, anxiety, and the use of labor analgesia, Archives of Women's Mental Health, 19(1): 11-16. doi: 10.1007/s00737-015-0572-6. 
Imanura PSI, Budiastuti UR, Poncorini E (2016). Efektifitas Hypnobirthing Untuk Menurunkan Tingkat Kecemasan Dalam Menghadapi Persalinan, Maternal and Childbirth Journal. Sebelas Maret University.

Prenoveau JM, Craske M G, Cooper P, Stein A, Murray L, West V, Giannakakis A (2017). Maternal postnatal depression and anxiety and their association with child emotional negativity and behavior problems at two years., Developmental psychology. American Psychological Association, 53(1): 50-62. doi: 10.1037/devoooo221.

Rahmi L (2010). Usia, Tingkat Pendidikan, Dukungan Suami, Dan Dukungan Keluarga Dengan Tingkat Kecemasan Menjelang Persalinan Pada Ibu Bersalin, Penelitian, Fakultas Keperawatan. Available at: http://repo.unand.ac.id/297/. Diakses 1 Oktober 2017.

Raybun WF (2014). Obstetri \&Ginekologi. Jakarta: EGC.

Risanto W (2010). Pengaruh Dukungan Psikososial Selama Persalinan Terhadap Rasa Nyeri Saat Persalinan, Lama Persalinan dan Kecemasan. Jurnal Kesehatan Masyarakat. Yogyakarta: UGM.

Rayment-Jones H (2017). A Multisite Audit to Assess How Women with Complex Social Factors Access and Engage with mMternity Services, Midwifery, 52: 71-77. doi: 10.1016/j.midw.2017.06.004 .

Riwidikdo H (2013). Statistik Kesehatan dengan Aplikasi SPSS dalam Prosedur Penelitian. Yogyakarta. Rohima Press.

Rose NW (2007). Panduan Lengkap Perawatan Kehamilan. Jakarta: Dian Rakyat.

Rini EV (2016). The Development and Psychometric Analysis of the Women's
Experience in Childbirth Survey. Journal of nursing measurement, 24(2): 268-280. doi: 10.1891/10613749.24.2.268.

Rospond RM (2009). Penilaian Nyeri: 133163. Available at: http://www.google.com/url?sa $=\mathrm{t} \& \mathrm{rct}=\mathrm{j} \& \mathrm{q}=\&$ esrc $=\mathrm{s} \&$ sou rce $=$ web\&cd $=3 \& c a d=r j a \& u a c t=8 \& v e d$ =oCCsQFjAC\&url=http://lyrawati.file s.wordpress.com/2008/o7/pemeriksa n-dan-penilaian-nyeri.pdf\&ei=AI6XVM6YPMa3uQShkIJI\&usg=AFQjCNE9P_7JeGmOmuxItY6-5mO6MUf5A\&sig2=SePY7CvQej_-

.Diakses pada 1 Oktober 2017

Saifudin (2010). Pelayanan Kesehatan Maternal dan Neonatal. Jakarta: Bina Pustaka.

Simkin P (2008). Buku Saku Persalinan. Jakarta: EGC.

Sofwan SSM (2000). Hukum Perdata dan Hak Milik Kebendaan. Yogyakarta: Liberty.

Sudarti, Judha MAF (2012). Teori Pengukuran Nyeri \&amp; Nyeri Persalinan'. Jakarta: Nuha Medika.

Suharso, Retnoningsih A (2005) Kamus Besar Bahasa Indonesia Edisi Lux by Suharso dan dra. Ana Retnoningsih. Jakarta: CV Widya Karya.

Sugiyono (2010). Statistika untuk Penelitian. Bandung: Alfabeta.

Sumampouw N (2008). Dukungan Psikososial: Satu Nama Dengan Banyak 'Wajah'. ; Artikel Pusat Krisis Fakultas Psikologi UI : Jakarta. Pp. 7-10

Terry R, Niven C, Brodie E, Jones R, Powse $M$ (2007). An exploration of the relationship between anxiety, expectations and memory for postoperative pain, Acute Pain, 9(3): 135-143. doi: 10.1016/j.acpain.2007.04.041.

Undang-undang Republik Indonesia No. 32 Tahun 2004 Tentang Pemerintahan Daerah. 
Journal of Maternal and Child Health (2018), 3(1): 44-58

https://doi.org/10.26911/thejmch.2018.03.01.05

Vollrath ME, Sengpiel V, Landolt MA, Jacobsson B, Latal B (2016). Is maternal trait anxiety a risk factor for late preterm and early term deliveries?, BMC Pregnancy and Childbirth. BMC Pregnancy and Childbirth, 16(1), p. 286. doi: 10.1186/s12884-016-1070-1.

Waqas A, Raza N, Lodhi HW, Muhammad Z, Jamal M, Rehman A (2015). Psychosocial factors of antenatal anxiety and depression in Pakistan: Is social support a mediator?, PLoS ONE,

10(1): 1-14. doi: 10.1371/journal.pone.0116510.

Wangmuba (2009). Pengertian Kecemasan. Diunduh dari http://wangmuba.com/2009 diakses pada 1 Oktober 2017.

Whitburn LY, Jones EL, Davey MA, Small R (2017). The Meaning of Labour Pain: How The Social Environment Shape Women's Experiences. BMC Pregnancy and Childbirth. Australia.

Wiramihardja S. 2016. Pengantar Psikologi Abnormal. Bandung; Refika Aditama. 